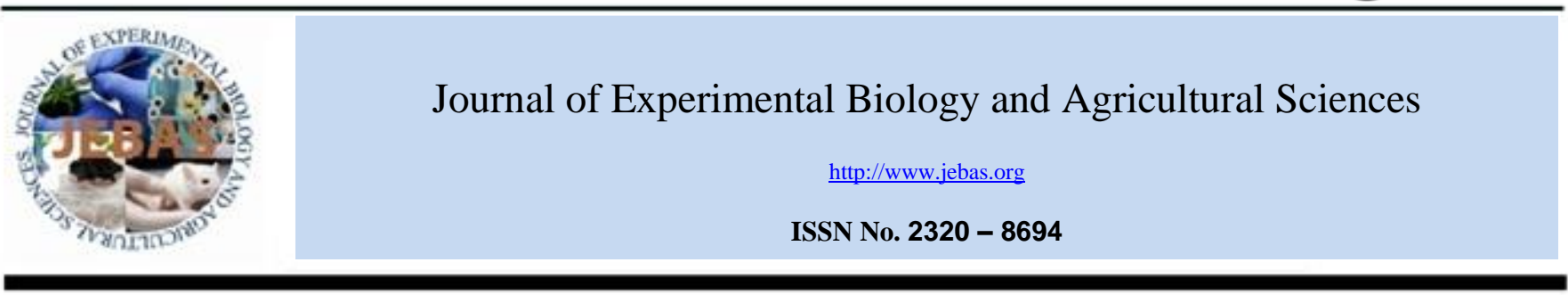

\title{
FARMER'S MANAGEMENT PRACTICES TO MAINTAIN THE GENETIC DIVERSITY OF SORGHUM (Sorghum bicolor L. MOENCH) IN SOUTH OF CHAD
}

\section{GAPILI Naoura* and DJINODJI Reoungal}

Institut Tchadien de Recherche Agronomique pour le Développement (ITRAD), B.P. 5400, N’Djaména, Tchad

Received - June 08, 2016; Revision - August 26, 2016; Accepted - October 26, 2016

Available Online - November 13, 2016

DOI: http://dx.doi.org/10.18006/2016.4(Issue6).625.630

\section{KEYWORDS}

Sorghum

Collection

Conservation

Genetic erosion

Chad

ABSTRACT

The objective of this study was to understand the farmer management practices in order to conserve the genetic diversity of sorghum and to determine the level of genetic diversity and local taxonomy in two regions (Logone Oriental and Moyen Chari) of the South of Chad. Total eight villages were visited and from these 53 accessions were collected from 116 inventoried accessions. The number of collected accessions varies from 3 to 9 per village and a loss of diversity was reported between 47 to $71 \%$ (average rate of $54.31 \%$ ) in all villages and this rate varies from village to village. Results of study revealed that the farmer nomenclature is based on the criteria of accession using, origin, color of seeds, type of panicle, crop cycle and the size of plants. This study suggested significant losses in the sorghum diversity of Chad. Therefore, there is a strong need to run a national program to collect, validate and protect the genetic resources of sorghum. This will be helpful in the reducing genetic erosion and to improve the varieties of sorghum cultivated in Chad.
\end{abstract}

* Corresponding author

E-mail: gap_pablo@yahoo.fr (GAPILI Naoura)

Peer review under responsibility of Journal of Experimental Biology and Agricultural Sciences.

Production and Hosting by Horizon Publisher India [HPI] (http://www.horizonpublisherindia.in/).

All rights reserved.
All the article published by Journal of Experimental Biology and Agricultural Sciences is licensed under a Creative Commons Attribution-NonCommercial 4.0 International License Based on a work at www.jebas.org.

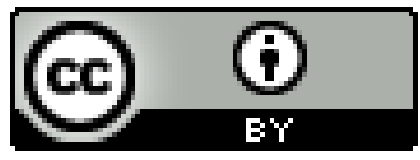




\section{Introduction}

Plant genetic resources related to food and agriculture are the biological basis of world food security (FAO, 2009). In Chad sorghum [Sorghum bicolor (L.) Moench] is the main cereal and it contributing approximately $38.6 \%$ of overall cereal production with a whole production of 360000 tons per year (CNC, 2001). Chad along with other West and Central African countries is considered as a secondary center of diversity of cultivated sorghums (Chantereau et al., 1997). Local cultivated varieties are adapted to the native environmental conditions and fulfill the various objectives of farmers. Despite the existence of research programs on genetic improvement of sorghum from the sixties through the Chadian Institute of Agricultural Research for Development (ITRAD), the adoption rate of selected varieties remained very low and it was reported between 2 to $5 \%$ of cultivated areas (Trouche et al., 2001). Producers are very closer to their accessions and they deliberately maintained millenniums, diversity and systematically mixed crops in their fields to get natural hybrids (Chambers et al., 1994). Prospecting allows to show the evidence then to exploit the diversity already existing but not revealed (Chantereau et al., 1997). This approach can significantly contribute in the creation of variability. The essential purpose of prospecting was to collect genetic material with the most possible variability, which can contribute in the actual improvement of sorghum crops. Prospecting is a way which helps in the protecting endangered species (Pernes, 1984). This study was conducted to determine the genetic diversity of sorghum's accessions in two regions of the Sudanian area of Chad. The accessions was collected and stored with a target of plant breeding and to know the mode of management of this diversity and the farmer's taxonomy of accessions.

\section{Materials and Methods}

\subsection{Study area}

Prospecting was conducted in the two regions viz Logone Oriental and Moyen Chari, these two are located in the Sudanian area of Chad. Study was conducted between 12 and 21 February 2016. The climate is tropical with alternating seasons, a wet season characterized by a rainfall running from
May to November and a dry season from November to May. The vegetation is characterized by Sudano-Sahelian savanna, slightly wooded in the north part but more planted with trees in the center, in the south, the savanna becomes as SudanoGuinean characterized by gallery forests. The Logone Oriental Region is divided into 6 districts and the Moyen Chari in 3 districts. Eight locations are selected on the basis of distance and geographic location so as to cover the maximum of different geographical areas concerned and get a representative sample.

\subsection{Method and collected data}

From each village, data were collected by using methods of participative research (inquiries of group and field visits) described by Orobiyi et al. (2013). In all surveyed villages, administrative and local authorities are involved in facilitating meetings in which information of general order (name of the village and ethnic group) was collected. After a brief display of the objectives of the research program to producers, they were asked to make a list of all local accessions (common names) still cultivated or not yet in the village. The samples were collected to ensure the effective presence of different varieties still cultivated and to set local synonym names difficulties. Through group discussion, retailed information's about morphological, agronomic and culinary descriptions (according to farmer perception) are also documented. Information on the vegetative cycle, origin of raw seeds, uses of each variety and the factors which determine the maintaining or disappearance of each of the local varieties was recorded on the collection sheet.

\section{Results}

\subsection{Surveyed villages and identified ethnic groups}

Sixteen villages were selected for the prospecting and among these only eight villages (table 1) were canvassed. In Logone Oriental, five villages were surveyed and Kouh Ouest department was cannot be explored because of unavailability of time during the study. While, in Moyen Chari provenance, the prospection covered the three districts and the department Bahr Kôh only two villages were surveyed. The study allows raising eight ethnic groups.

Table 1 Villages and ethnic group statements.

\begin{tabular}{|c|c|c|c|c|}
\hline Region & Department & Sub-prefecture & Villages prospected & Groupethnic \\
\hline \multirow{5}{*}{ Logone Oriental } & Monts de Lam & Bessao & Kamkoutou & Laka \\
\hline & NyaPendé & Goré & Timbéri & Kaba \\
\hline & Nya & Beboni & Mbanguirati 2 & Ngambaye \\
\hline & Pendé & Kara & Maïbombaye & Mongoh \\
\hline & Kouh Est & Bédjo & Békodo & Gor \\
\hline \multirow{3}{*}{ Moyen Chari } & Bahr Kôh & Djoli & Doguigui, Doboro & Sarah Madjingaï \\
\hline & Grande Sido & Maro, & Kobdogué & Ngama \\
\hline & Lac Iro & Kyabé & Guilagondéré & Sarah Kaba \\
\hline
\end{tabular}


3.2. Varietal diversity of sorghum and farmers management practices

Fifty three accessions of sorghum grain were collected, among these thirty four (34) were collected from Logone Oriental while rest nineteen (19) were collected from Moyen Chari. In Logone Oriental (Table 2), most of the accessions were collected from the village Timbéri and Mbanguirati 2 (9 accessions from each village), these were followed by Maïmbombaye ( 8 accessions) then by Kamkoutou (5 accessions) and finally by Bekodo 2 (3 accessions). An average of 6.8 accessions per village was collected in Logone Oriental, which determines an important genetic diversity. In Moyen Chari (Table 3) total 19 accessions were collected, among these 8 were collected from the village Djoli, 7 from the Guilagonderé and rest 4 from the village of Kobdogué. This represents collection of 6.3 accessions per village from this region, characterizing an important genetic diversity.

Surveyed, producers manage accessions according to the vegetative cycle in early and late raining season. Starting from the first rains of the month of May, farmers firstly sow accessions of delayed cycle followed by some accessions of early cycle which will be reaped in the month of August which is considered as lean period. The extra-early accessions harvested during the lean season, are planted around huts and other accessions are planted in the fields of bush in most of the cases in association of culture.

Table 1 Sorghum accessions collected from the Logone Oriental region.

\begin{tabular}{|c|c|c|c|c|}
\hline S. N & Village & Local name of the accessions & Meaning & Characteristics \\
\hline 1 & \multirow[t]{5}{*}{ Kamkoutou } & MougayeBonwing & - & Semi-compact, early \\
\hline 2 & & Ngoumhkass & Ngoumh red & Compact, red grains \\
\hline 3 & & Djingandoule & Glumes black & Red grain \\
\hline 4 & & Wakass & Sorghum with red grain & Red grain \\
\hline 5 & & Wanda & Sorghum with black grain & White grain \\
\hline 6 & \multirow[t]{9}{*}{ Timberi } & DôMbä̈meldjé & - & Grain and flour red \\
\hline 7 & & Madamkass & Madam red & Extra-early, white \\
\hline 8 & & BéléNda & Bélé white & Extra-late, old \\
\hline 9 & & MadamNda & Madame white & Extra-early, white \\
\hline 10 & & DjeMba On djingal & Visitor does not eat broken & White grain \\
\hline 11 & & Djakadji & We are saved & White grain \\
\hline 12 & & Garidjéjaune & - & Yellow grain \\
\hline 13 & & Garidjeé blanc & - & Grain and flour white \\
\hline 14 & & Bindocodo & Braided hair of the rebels & - \\
\hline 15 & \multirow[t]{9}{*}{ Mbanguirati 2} & TelBaou On el & easy to become a great producer & - \\
\hline 16 & & KouranMbao & - & Early, white grain \\
\hline 17 & & Mir & - & Ancestral, red grain \\
\hline 18 & & Mainmbororo & flee the cattle-breeders & Early \\
\hline 19 & & Am-Timan & From Am-Timan & Red grain \\
\hline 20 & & Madam & Madam & Early \\
\hline 21 & & Godard & Brought by Godard & $\begin{array}{l}\text { White, grain entirely covered } \\
\text { of glumes }\end{array}$ \\
\hline 22 & & Moyo & Seedeath & Red grain \\
\hline 23 & & Ingadombandje & Braided hair of the "peules" & - \\
\hline 24 & \multirow[t]{8}{*}{ Maïmbombaye } & MbatNang-Al & Do not refuse the ground & Yellow grain \\
\hline 25 & & Ngagetdjé & - & White grain, early \\
\hline 26 & & Yingté & - & Early, loose panicle, red grain \\
\hline 27 & & Malcamion-Al & I do not take up the truck & - \\
\hline 28 & & Godji & Short & Sweet stem, early, red \\
\hline 29 & & Kouranngang & - & - \\
\hline 30 & & Kolmonnda & Kolmon white & White grain \\
\hline 31 & & Galidjé & & - \\
\hline 32 & \multirow[t]{3}{*}{ Bekodo 2} & Tamadekass & - & Considered, grain red. \\
\hline 33 & & Bére & - & Big and white grain \\
\hline 34 & & Godji & Short & - \\
\hline
\end{tabular}


3.3 Sorghum diversity and farmer ethnobotanic knowledge of taxonomy

The study showed that farmers used variable nomenclature of accessions and it varies between various ethnic groups. Several criteria are used to assign various name to the available accessions and basically it depends on the shape of the panicle, colors of seeds, use reserved for each accession and its origin. For example in Kamkoutou there is an accession named "Djingandoule", which means black husk in Laka and "WaKass" mean ingred sorghum grain. In Timberi accession "DjeMba Ondjingal" means, in Kaba, "visitor does not eat broken" because the grinding is difficult and seeds are very glassy and very tough. Further, in Mbanguirati 2 the accession "Tel Baou On el" meaning Ngambaye, it is easy to become a great producer because of its high production. In Maïbombaye the accession "Mbat Nang $\mathrm{Al}$ " means in Mongoh, something suitable for any type of soil. In Bekodo 2 the accession "Godji", also met with Maïbombaye, means in both villages short sorghum. The accession "Moyo" of Mbanguirati 2, which means seeing the death, is very old in the village and is used to take the oath in a dispute between two parts.

The accessions collected from the Moyen Chari region were also showed diversified nomenclature like the previous region and it varies between ethnic groups to ethnic group and within each group. The characteristics of panicles, color of grains and special use types are determining in the farmer taxonomy. There is "Godji" in Guilagonderé and in Djoli meaning short sorghum. An accession named "Fall" met in Kobdogué is extra-late and white grain, but its culture is increasingly rare because of the threat of cattle breeders.

\subsection{Genetic erosion of sorghum diversity}

Table 4 shows the contribution of villages in the conservation of genetic diversity and presents the rate of loss of sorghum genetic diversity. In Kamkoutou (Logone Oriental region), over $70 \%$ of accessions identified by producers during the investigation, and could not be collected. In the region of Moyen Chari, the village Maro showed the biggest loss with more than $71 \%$ of not collected accessions.

Several reasons including reducing rainfall cycle are mentioned by producers; these are resulted in the loss of traditional accessions which are usually late-cycle. Also the method of conservation which consists to beat the bulk seed to keep them in bags, because the method collect of this present study requires taking a whole panicle to avoid mixtures of accessions. For some producers the period of collection and the unpredictable of the prospecting mission did not allow gather all accessions still cultivated in the village.

Table 2 The sorghum accessions collected from the Moyen Chari region.

\begin{tabular}{|c|c|c|c|c|}
\hline S.N. & Village & Local name of the accessions & Meaning & Characteristics \\
\hline 35 & Guilagonderé & Bambara & & \\
\hline 36 & & Absolue & Product absolutely & Dwarfish and productive \\
\hline 37 & & GodjiKoh & Short sorghum & Red grain \\
\hline 38 & & Gad & & Panicle compact, white grain \\
\hline 39 & & Godjiprécoce & Sorghum short and early & Red grain \\
\hline 40 & & Toundou & & Red grain \\
\hline 41 & & Kelmani & Brought by Kelmani & \\
\hline 42 & Kobdogué & Fall & & Extra-late, white grain \\
\hline 43 & & Fall précoce & Fall early & Early, yellow grain \\
\hline 44 & & Gad & & Stem big and sweet, red grain \\
\hline 45 & & Am Timam & From Amtiman & $\begin{array}{l}\text { Early, red grain, cultivated on all } \\
\text { type of soil }\end{array}$ \\
\hline 46 & Djoli & Lakemdar & & Red grain, promising \\
\hline 47 & & NgaguetDje & & White grain, tall height \\
\hline 48 & & GuidGodji & Harvests after Godji & Red grain \\
\hline 49 & & Kamsa & & Red grain \\
\hline 50 & & Air Djimra & Introduce by Djimra & Red grain \\
\hline 51 & & Bouroum & Ostrich & White grain \\
\hline 52 & & Gali & On the level of thigh & White grain \\
\hline 53 & & Godji & Short & Red grain \\
\hline
\end{tabular}


Table 3 Accessions identified and loss rate of sorghum diversity per village.

\begin{tabular}{|llccc|}
\hline Regions & Villages & Accessions identified & Accessions collected & \% of loss \\
\hline Logone Oriental & Kamkoutou & 17 & 5 & 70.6 \\
\hline & Timberi & 18 & 9 & 50 \\
\hline & Mbanguirati 2 & 17 & 9 & 47 \\
\hline & Maimbomaye & 17 & 8 & 53 \\
\hline & Bekodo 2 & 8 & 3 & 52.5 \\
\hline Total 1 & & 77 & 7 & 55.84 \\
\hline Moyen Chari & Guilagondere & 14 & 4 & 50 \\
\hline & Maro & 14 & 8 & 71.43 \\
\hline & Djoli & 11 & 19 & 26.27 \\
\hline Total 2 & & 39 & $\mathbf{5 3}$ & 51.28 \\
\hline Total 1+2 & & $\mathbf{1 1 6}$ & $\mathbf{5 4 . 3 1}$ \\
\hline
\end{tabular}

\section{Discussions}

The study allowed collecting 53 accessions, with 3 to 9 accessions collected by village, which represents an average of 6.62 accessions by village. This inventory is not exhaustive; because it is likely that minor varieties have gotten away, and the cultivated variety is constantly evolving. This average accession number is higher than the Gapili et al. (2016), those who collected 2.84 accessions per village on sweet sorghum from Chad. This established the existence of an important genetic diversity in this study which was managed by farmers. This value is higher than the obtained by Missihoun et al. (2012) and Sawadogo et al. (2015) those who obtained 5.54 and 1.24 values in sorghum of Benin and Burkina Faso respectively. This important genetic diversity of Chad sorghum represents a major advantage for the programs of genetic improvement of this crop.

Farmers managed a varied cycle of diversity ranging from extra-early to late using by the way intermediaries which they sow depending on the rain. This spatial organization significantly enhances the flow of genes between favorable accessions to the increasing of genetic diversity within and between accessions. It confirms the work of Barnaud et al. (2007) at Cameroonian farmers who cultivate sorghum in polyvarietal blend, but it is contrary to the Beninese producer management practices which have predominantly separate culture technique for the different varieties (Missihoun et al., 2012).

The farmer taxonomy is based on the shape of the panicle, seed color, cycle, plant size and the type of using. According to Sawadogo et al. (2015), a perfect knowledge of the names given to the varieties and the traditional classification system is important to the extent that the local name is the basic unit used by producers in the management and selection of genetic resources. This expertise has consequences both on the level of genetic diversity and on the evolution of the plant (Brocke et al., 2003; Barry et al., 2007). The accession "Djingandoule" met in Kamtoukou indicates the black color of the hull. In Timberi, the accession "DjeMba Ondjingal" which means, "the visitor does not eat broken" evokes the very glassy character of the seed. The accession "Mainmbororo" means flees cattlebreeders indicates here the character of precocity allowing harvesting these accessions before the arrival of nomadic herdsman. In Djoli, the accession "Gali" meaning as high as the thigh, relates to the character of small size of the plant. Thus, a good knowledge of the farmer naming allows understanding their diversity management mode and integrate it in a breeding program to create varieties adapted to their objectives.

The study shows a significant loss of diversity in sorghum accessions ranging from 47 to $71 \%$ by village. According to FAO (2010), three quarters of the genetic diversity of cultivated crops have been lost over the twentieth century. Several reasons are reported by producers to explain this genetic diversity loss. Among these, reduction in the rainfall cycle is most important one and it is responsible for the abandonment of several long cycle varieties, the most appreciated by producers. According to Lambert (1983), still there are farmers those who attached to their traditional longer cycles varieties than the modern varieties. In Timberi accession "BéléNda" of extra delayed cycle is by far the most liked by farmers with the most expensive selling value but it is less and less grown because of the reduction in the seasonal rain due to climate change. Secondly the presence of transhumant's cattlebreeders in the growing area is a real threat, which leads to the abandonment of late cycle accessions. Indeed, some accessions of late cycle can still be grown despite the reduction in the rainfall cycle, because of their resistance to drought and pouring. However, their culture is abandoned because of the presence of cattle-breeders. This is the case of accession "Fall" met to Kobdogué, extra-late cycle whose culture is increasingly rare because of the threat of cattle-breeders.

This study clearly shows that sorghum production in the study area is increasingly oriented towards short cycle accessions. This supports the work of Missihoun et al. (2012) who found that sorghum producers in Benin are moving towards short growing season accessions because of irregular periods of rain 
and drought marked by the significant reduction in time rain and the market value of short vegetative cycle accessions.

\section{Conclusion}

In present study total 53 accessions of sorghum which were cultivated in the regions of Logone Oriental and Moyen Chari was collected, with an average of 6.62 accessions per village, characterizing the important genetic diversity of sorghum in Chad. Producers use a local taxonomy to name accessions, adding the using reserved for accessions, the type of panicle, the cycle, the seed color and plant size. A good handling of this nomenclature is an asset for the management of the genetic diversity of these accessions and creating a "core collections". The study reveals a significant loss of genetic diversity, characterized by abandonment of accessions extra-late vegetative cycle by producers. The rate of this loss is around $54.31 \%$, ranging from 47 to $71 \%$ by village, constituting a real threat for the biodiversity of this culture. Prospection perspective should be considered for the recovery and conservation of the diversity of sorghum accessions in Chad.

\section{Acknowledgement}

We thank the Project "Opérationnalisation de la filière semencière au Tchad", of the GIZ financed by the Suisse cooperation which provided financial support for this work.

\section{Conflict of interest}

Authors would hereby like to declare that there is no conflict of interests that could possibly arise.

\section{References}

Barnaud A, Deu M, Garine E, Mc Key DJoly HI (2007) Local genetic diversity of sorghum in a village in northern Cameroon: structure and dynamics of landraces. Theorical and Applied Genetics114:Pp. 237-248. DOI:10.1007/s00122-0060426-8

Barry MB, Pham JL, Courtois B, Billot C, Ahmadi N (2007) Rice genetic diversity at farm and village levels and genetic structure of local varieties reveal need for in situ conservation. Genetics Resources and Crops Evolution 54: 1675-1690.

Brocke VK, Christinck A, Weltzien ER, Presterl T, Geiger HH (2003) Farmer's seed systems and management practices determine pearl millet genetic diversity patterns in semiarid regions of India. Crops Sciences 43: Pp. 1680-1689.

Chambers R, Pacey A, Thrupp LA, (1994) Les paysans d'abord : les innovations des agriculteurs et la recherche agronomique. CTA, Karthala, Pp. 346.
Chantereau J, Trouche G, Luce C, Deu M, Hamon P (1997) Le sorgho. In : A. Charrier, Jacquot M, Hamon S, Nicolas D (Eds,), L'amélioration des plantes tropicales. Collection Repères, Pp. 565-590.

Comité National de Concertation Tchad (2001) Initiative mil et sorgho étude sur la filière mil et sorgho- Rapport.

FAO (2009) The state of food and agriculture Pp. 180.

FAO (2010) La FAO s'inquiète de l'érosion de la diversité génétique des plantes. Available on m.actuenvironnement.com/actualites/diversite-vegetale-semencesbanques-genes-fao-11281.htlml access on April, 2015.

Gapili N, Nodjasse AD, Djinodji R, Djondang K (2016) Prospection et Collecte des accessions de sorgho sucré Sorghum bicolor (L.) Moench - du Tchad. Journal of Applied Biosciences 100:9504 - $\quad 9514 . \quad$ DOI: http://dx.doi.org/10.4314/jab.v100i1.2.

Lambert C (1983) Influence de la précocité sur le développement du mil en conditions naturelles. I. Elaboration de la touffe. Agronomie Tropicale 38 : 7-15.

Missihoun AA, Agbangla C, Adoukonou-Sagbadja H, Ahanhanzo C, Vodouhè R (2012) Gestion traditionnelle et statut des ressources génétiques du sorgho (Sorghum bicolor $\mathrm{L}$. Moench) au Nord-Ouest du Bénin. International Journal of Biology and Chemistry Sciences 6: 1003-1018.

Orobiyi A, Dansi A, Assogba P, Loko LY, Dansi M, Vodouhè R, Akouègninou A, Sanni A (2013) Chili (Capsicum annиum L.) in southern Benin: production constraints, varietal diversity, preference criteria and participatory evaluation. International Research Journal of Agricultural Science and Soil Science 3: 107-120.

Pernes J (1984) Gestion des ressources génétiques des plantes. Agence de Cooperation Culturelle et Technique. Paris, Pp. 346.

Sawadogo N, Nanema RK, Bationo-Kando P, Traore RE, Nebie B, Tiama D, Sawadogo M,Zongo JD (2015) Evaluation de la diversité génétique des sorghos à grains sucrés (Sorghum bicolor (L.) Moench) du Nord du Burkina Faso. Journal of Applied Biosciences 84:7654- 7664. DOI: http://dx.doi.org/10.4314/jab.v84i1.3.

Trouche G, Da S, Palé G, Sohoro A, Ouédraogo O, Gosso D (2001) Evaluation participative de nouvelles variétés de sorgho au Burkina Faso. In : Hocdé H, Lançon J, Trouche G (Eds.) La sélection participative : impliquer les utilisateurs dans l'amélioration des plantes. Actes de l'atelier de Montpellier (France). 